\title{
Inpatient Treatment - a Matter of Social Background in Germany
}

\author{
Fabian Holbe ${ }^{1,2}$ \\ ${ }^{1}$ Hausarztpraxis Neuburg, Neuburg, Germany \\ ${ }^{2}$ Project Management, Hochschule Wismar, Wismar, Germany
}

Email address:

Holbe@Hausarztpraxis-Neuburg.de

\section{To cite this article:}

Fabian Holbe. Inpatient Treatment - a Matter of Social Background in Germany. Science Journal of Public Health. Vol. 9, No. 5, 2021, pp. 169-172. doi: 10.11648/j.sjph.20210905.15

Received: September 12, 2021; Accepted: September 29, 2021; Published: October 12, 2021

\begin{abstract}
Hospital financing in Germany is based on the principle of "dual financing": the operating costs of the hospitals, i.e. all costs that arise for treating patients, are financed by the health insurance companies. The investment costs, however, are financed by the federal states. The remuneration of the hospitals by the health insurance companies is based on the DRG system, which is a flat-rate billing system in which inpatient hospital treatments are billed as flat-rate fees, largely regardless of the length of the patient's stay. The DRG system is currently the subject of criticism because it makes it more difficult for children's clinics to cover costs, especially in pediatrics. On the basis of hospital billing data, there is a connection between the socio-economic status of a family and the likelihood of hospitalization in the event of a child's illness. The likelihood of inpatient treatment for certain pediatric diseases is significantly higher in economically weaker federal states. A proportionately higher inpatient treatment capacity is available in the affected federal states for this higher need. Should the poor financial situation of the federal states lead to the number of beds being rationed, the quality of care will deteriorate, especially for these children.
\end{abstract}

Keywords: Solidarity, Inpatient Pediatrics, Hospital Care

\section{Introduction}

Given the background of rising health care costs, rationing debates are increasingly being conducted publicly. The provision of inpatient pediatric services is no exception. In particular, general pediatrics is not considered economically attractive within the specialist departments for the hospital operator [1]. It is important to analyze the affected patient groups in detail in order to counteract any exclusion of services to the detriment of the affected children and their families. Otherwise, the social disadvantage threatens to develop into a health impairment. The closure of departments and even entire clinics is no longer a distant vision of the future, at least since the Bertelsmann Foundation study [2].

\section{Background}

Bremen, Mecklenburg-Western Pomerania and SaxonyAnhalt are the federal states with the highest at-risk-ofpoverty rate [3]. At the same time, most of the pediatric beds
/ 100,000 inhabitants are provided by these federal states (figure 1).

In terms of their economic strength, however, they are among the financially weak countries. Since in the dual system of hospital financing investment costs have to be paid from the respective state budgets, there is a risk of a health policy based on the cash situation. For the clinic operators, children's clinics are of subordinate economic interest. Small children's clinics are affected or threatened by closings [1]. However, the birth rate has increased nationwide by as much as $19 \%$ since 2011 [4].

The number of chronically ill children, e.g. with diabetes, asthma and obesity, is also increasing, meanwhile every sixth child suffers from a chronic health disorder [5].

The need for inpatient treatment capacities in pediatrics should therefore increase.

In Germany, the number of pediatric beds in the period from 2007 to 2017 fell by $0.6 \%$ to 18,591 [6]. The German Academy for Pediatric and Adolescent Medicine considers 30 beds as the minimum size for economic operation [7]. 
In the event of a children's clinic being closed, the surrounding clinics would have to cover the ongoing demand. Since, according to the UN Charter [8], only one other children's clinic is considered for treatment.

The aim of the care structures is to provide appropriate care for children.

\section{Need for specialized impatient treatment}

For adult patients with heart failure it could be shown that the outcome was significantly improved by treatment by specialized high-volume cardiologists than by treatment by non-specialized internists without a cardiological focus [9]. Comparable results could also be shown in the internal specialties gastroenterology and endocrinologist for the performance of colonoscopies and the treatment of patients with diabetes mellitus [10].

If the trend in conservative medicine and in pediatrics were to continue towards high volume, it would be desirable. The integration of highly specialized centers in the concept of the maximum care clinic makes sense in particular for diseases whose therapeutic success depends on pronounced interdisciplinary cooperation. The advantages of specialization and integration can be used to a great extent here. The accessibility of such highly specialized centers from sparsely populated and economically weaker regions is difficult to implement in practice and unnecessary in common illnesses.

Impatient or outpatient treatment in common illnesses

The indication for inpatient admission does not only depend on the severity of the disease. For this purpose, the clinical picture of community-acquired pneumonia should be taken as an example

The current recommendation for action according to the $\mathrm{S} 2 \mathrm{k}$ guideline [11] provides for a "social indication" to be included in order to decide whether admission to inpatient treatment appears necessary in the case of a non-severe course of community-acquired pneumonia.

\section{Material and methods}

To investigate a possible connection between social status, which is a possible criterion for a "social indication", and the frequency of admission to pediatrics, the following typical general pediatric clinical pictures were examined:

1) ICD 10 "J06" \& "J20-J22": Infections of the upper and lower respiratory tract

2) ICD 10 "K59": Other functional bowel disorders

3) ICD 10 "R10-R19": Symptoms that affect the digestive system and abdomen

4) ICD 10 "R50-R69": Symptoms and abnormal clinical and laboratory findings not elsewhere classified

The following data sets were used for the calculation:

A. Billing data by federal state, ICD 10 diagnosis code for the year 2019 in the specialist group code for general pediatrics based on the data according to $\S 21 \mathrm{KHEntgG}$

B. Inpatient beds in paediatrics

C. Population of the federal states according to information from the Federal Statistical Office

D. Youth quotient, i.e. the percentage of those under 20 years of age in the age group up to 65 according to information from the Federal Statistical Office from 2016 [12].

E. At-risk-of-poverty rate according to information from the Federal Statistical Office "The at-risk-of-poverty rate is the proportion of people with an equivalised disposable income (after social transfers) below the atrisk-of-poverty threshold, which is $60 \%$ of the national median equivalised disposable income (after social transfers). This indicator does not measure prosperity or poverty, but rather a low income (compared to other people in the same country), which does not necessarily mean a low standard of living." [3]

F. In order to analyze possible confounders, the analysis of:

1) Proportion of smokers in the respective federal state [13].

2) Proportion of single parents in the respective federal state [14].

3) At-risk-of-poverty rate of households with two adults with three or more children in 2012 in the respective federal state [15] (Federal Statistical Office, 2012)

The data sets were calculated as follows:

(Number of the ICD10 diagnosis "in the respective federal state") / (Population * youth quotient)

The individual diagnoses were set in relation to the population and the youth quotient. The correlation analysis was calculated according to Bravais-Pearson (SPSS).

\section{Results}

With 32.2 pediatric beds per 100,000 inhabitants, SaxonyAnhalt has the highest bed density, followed by Bremen (29.7), Thuringia (29.2) and Mecklenburg-Western Pomerania (28.4) (see Figure 1). The average occupancy rate at the children's clinics is $65.4 \%$. According to the 2018 Hospital Rating Report, bed occupancy in hospitals across all departments was $77.5 \%$, but it depends on the number of beds in the hospital $(64.1 \%$ for $1-49$ beds up to $80.1 \%$ for more than 800 Beds). Clinics with fewer beds are particularly common in rural areas.

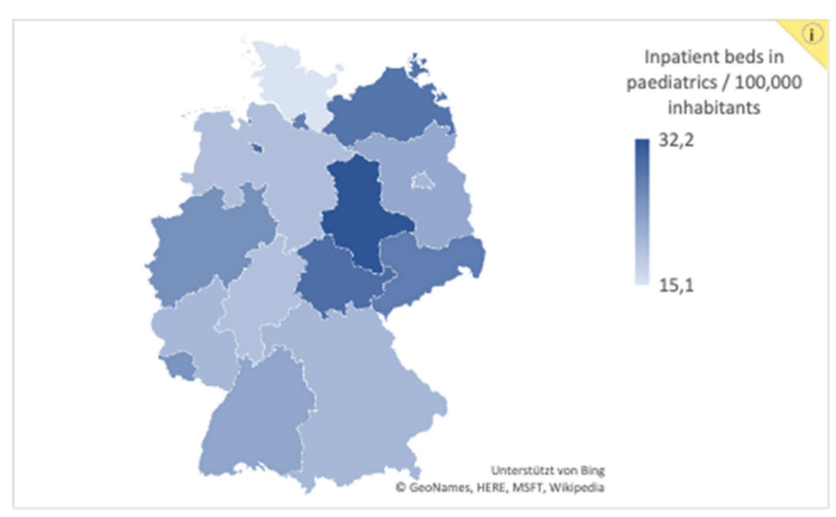

Figure 1. Pediatric beds by federal state (own illustration).

Bremen has the highest at-risk-of-poverty rate with $22.7 \%$, followed by Mecklenburg-Western Pomerania (20.9\%) and Saxony-Anhalt (19.5\%). 
The at-risk-of-poverty rate increases significantly when families with two adults and two or more children are considered. Mecklenburg-Western Pomerania has the highest value with $46.1 \%$, followed by Bremen (45.3\%) and Berlin (41.4\%) (see Figure 2).

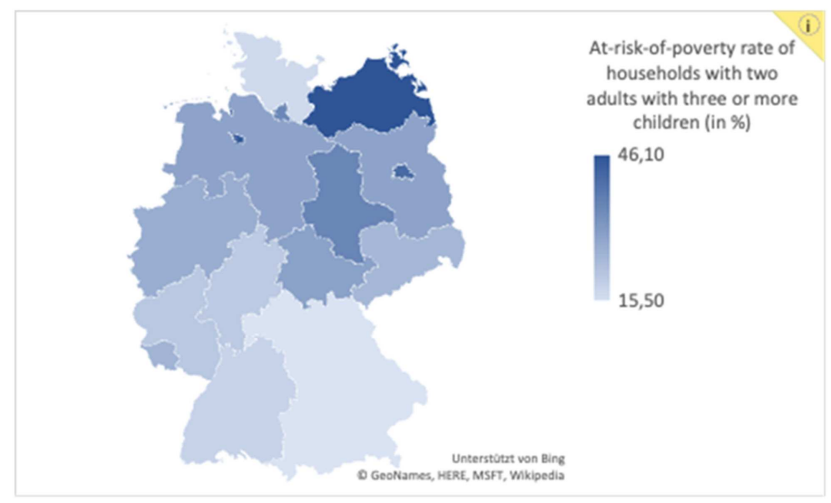

Figure 2. At-risk-of-poverty rate among larger families by federal state (own illustration).

The share of single parents is highest in Berlin at 27.6\%, followed by Saxony-Anhalt (25.6\%) and MecklenburgWestern Pomerania (25.5\%).

The proportion of smokers, due to the possible influence in particular on the diagnoses "J06", "J18", "J20-J22", is highest in Brandenburg at $42.6 \%$, followed by MecklenburgWestern Pomerania (33.5\%) and Berlin (32.2\%) (see Figure 3).

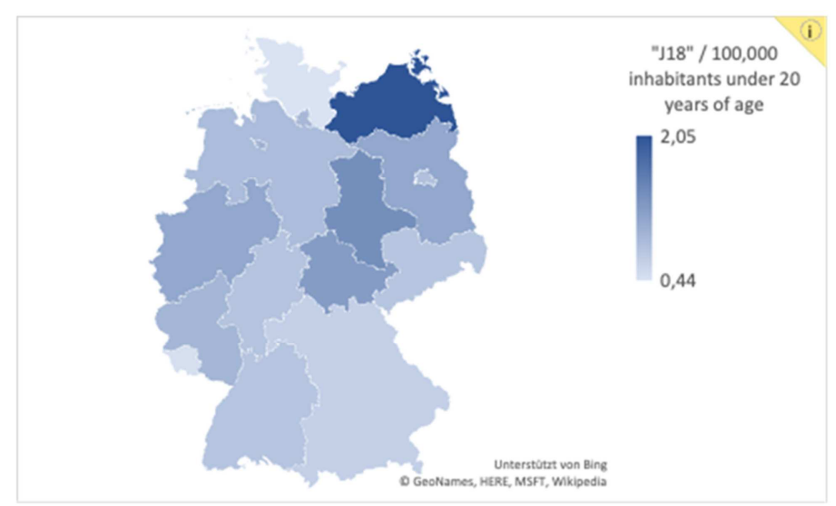

Figure 3. ICD "J18" / 100,000 inhabitants under 20 years of age (own illustration).

In the further data analysis, the number of pediatric beds kept correlated strongly with the number of inpatient treatment cases $(\mathrm{r}=.848, \mathrm{p}<.001)$ as well as with infections of the upper respiratory tract $(\mathrm{r}=.683 \mathrm{p}<.005)$ and abnormal laboratory findings $(\mathrm{r}=.734 \mathrm{p}=.001)$.

A correlation at the level of 0.05 is, based on the number of beds available, for the single parent rate $(\mathrm{r}=.573, \mathrm{p}=.02)$, the at-risk-of-poverty rate $(\mathrm{r}=.580, \mathrm{p}<.02)$ and the frequency of admission of those examined Colon-related diagnosis groups $(r=.600, p<.02)$ and the frequency of referral for functional abdominal complaints $(r=.604, p<.02)$.

In the analysis of the number of cases related to the population share in the respective federal state, it is noticeable that the number of cases correlates strongly with almost all diagnostic groups examined (diagnoses "R10-R19": r.819, p<.001; diagnoses "J06 \& J20-J22" r.674 p<0.005; diagnosis "K59" r.761, $\mathrm{p}=.001$, diagnoses "R50-R69" r=.811, $\mathrm{p}<0.001)$.

In addition to the described correlation with bed density and number of cases, the single parent rate shows a high correlation with the at-risk-of-poverty rate $(r=.664, p=.005)$ and the at-risk-of-poverty rate with an above-average number of children $(\mathrm{r}=.846, \mathrm{p}<.000)$.

Only the ICDs "R10-R19" were significant among the admissions numbers of the examined diagnostic groups $(\mathrm{r}=.503, \mathrm{p}<.05)$.

The at-risk-of-poverty rate, as well as the at-risk-ofpoverty rate in larger families, show no correlation with one of the selected diagnostic groups.

The proportion of smokers and the frequency of the diagnosis "J18" do not correlate with any other research item. The other diagnosis groups all correlate with each other $(\mathrm{r}>.648, \mathrm{p}<.007)$.

\section{Summary}

Overall, based on the available data, there is a connection between the number of beds available and the number of inpatient cases within a federal state. Both the rate of single parents within a federal state and the at-risk-of-poverty rate are associated with an increased number of cases and beds in the respective federal state. The proportion of smokers has no relation to the diagnoses examined, the economic status or the number of beds in a federal state. There was also no correlation between the proportion of smokers in a federal state and the risk of poverty.

According to the available data, children from socially disadvantaged families are statistically more dependent on inpatient treatment than children from economically better off parents. This need for treatment capacity is met by keeping a higher number of pediatric beds in the poorer federal states. In this context, children's clinics perform a social task to improve the equality of opportunity for children. Due to the current system of hospital financing, however, it depends on the budget situation of the federal states whether this contribution to equal opportunities can be made.

\section{References}

[1] Weyersberg A, Roth B, Köstler U, Woopen C. Pädiatrie: Gefangen zwischen Ethik und Ökonomie. Dtsch Arztebl International. 2019; 116 (37): A-1586 / B-1308 / C-1287.

[2] Loos S, Albrecht M, Zich K, Zukunftsfähige Krankenhausversorgung Simulation und Analyse einer Neustrukturierung der Krankenhausversorgung am Beispiel einer Versorgungsregion in Nordrhein-Westfalen. Bertelsmann-Stifung 2019 https://www.bertelsmannstiftung.de/de/publikationen/publikation/did/zukunftsfaehigekrankenhausversorgung. 
[3] Bundesamt S. Armutsgefährdungsquote in Deutschland nach Bundesländern im Jahr 20182019 [Available from: https:/de.statista.com/statistik/daten/studie/164203/umfrage/a rmutsgefaehrdungsquoten-in-den-bundeslaendern/.

[4] Bundesamt S. (16. Juli, 2021). Anzahl der Geburten in Deutschland von 1991 bis 2020 [Graph]. In Statista. Zugriff am 27. September 2021, von https:/de.statista.com/statistik/daten/studie/235/umfrage/anza hl-der-geburten-seit-19937.

[5] Neuhauser H, Poethko-Müller C, Ki GGSSG (2014) Chronische Erkrankungen und impfpräventable Infektionserkrankungen bei Kindern und Jugendlichen in Deutschland. Bundesgesundheitsblatt - Gesundheitsforschung - Gesundheitsschutz 57: 779-788.

[6] Bundesregierung. Drucksache 19/7270 2019 [Available from: http://dip21.bundestag.de/dip21/btd/19/072/1907270.pdf.

[7] Institut I. Kinder- und Jugendmedizin in MecklenburgVorpommern Wissenschaftliche Untersuchung über die Zukunft der flächendeckenden medizinischen Versorgung im Fachgebiet Kinder- und Jugendmedizin in MecklenburgVorpommern: Ergebnisbericht im Auftrag des Ministeriums für Arbeit, Gleichstellung und Soziales in MecklenburgVorpommern; 2015 [Available from: https://www.iges.com/e6/e1621/e10211/e10849/e11764/e1176 9/e11771/attr_objs11774/IGESInstitut_Bericht_KinderundJug endmedizininMecklenburgVorpommern_ger.pdf.

[8] EACH, Charter for Children in Hospital. Gesundheits- und Kinderkrankenpflege. Hoehl M, Kullick P, Hrsg. 5., aktualisierte Auflage. Stuttgart: Thieme; 2019. doi: 10.1055/b006-163248.

[9] Joynt K. E., Orav E. J., Jha A. K. 2013. Physician volume, specialty, and outcomes of care for patients with heart failure. Circ Heart Fail, 6, 890-7.
[10] Pace D., Borgaonkar M., Lougheed M., Marcoux C., Evans B., Hickey N., O'leary M., Boone D. \& Mcgrath J. 2016. Effect of Colonoscopy Volume on Quality Indicators. Can J Gastroenterol Hepatol, 2016, 2580894.

[11] Diesner SC, Voitl P. Handlungsempfehlung nach der S2kLeitlinie „Management der ambulant erworbenen Pneumonie bei Kindern und Jugendlichen (pCAP)“. Monatsschrift Kinderheilkunde. 2020; 168 (4): 360-2.

[12] Bundesamt S. Bevölkerungsfortschreibung 2016 auf Grundlage des Zensus 2011. Bevölkerungsfortschreibung 2016 auf Grundlage des Zensus 2011. 2019: 25.

[13] Kotz D, Böckmann M, Kastaun S. Nutzung von Tabak und EZigaretten sowie Methoden zur Tabakentwöhnung in Deutschland. Dtsch Arztebl International. 2018; 115 (14): 235-42.

[14] Bundesamt S. (2. August, 2018). Anteil der Alleinerziehenden an allen Familien mit minderjährigen Kindern in Deutschland nach Bundesländern in den Jahren 1997 und 2017 [Graph]. In Statista. Zugriff am 28. September 2021, von https://de.statista.com/statistik/daten/studie/900210/umfrage/a nteil-der-alleinerziehenden-an-allen-familien-mitminderjaehrigen-kindern/.

[15] Bundesamt S. (13. August, 2020). Sozialberichterstattung Armutsgefährdungsquote gemessen am Bundesmedian nach Haushaltstyp https://www.destatis.de/DE/Themen/GesellschaftUmwelt/Soziales/Sozialberichterstattung/Tabellen/06agqzvbm-haushaltstyp.html. 